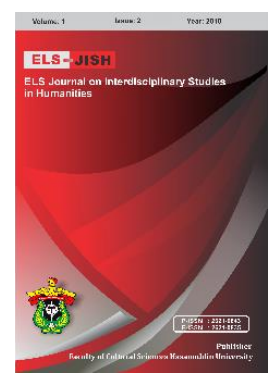

ELS-JISH

ELS Journal on Interdisciplinary Studies on Humanities

Volume 1 Issue 2, 2018

ISSN (print) : 2621-0843

ISSN (online) : 2621-0835

Homepage : http://journal.unhas.ac.id/index.php/jish

\title{
Late Prehistoric Burial System in South Sulawesi
}

\author{
Akin Duli ${ }^{*}$, Rosmawati $^{2}$ \\ *e-mail of Corresponding Author: akinduli@unhas.ac.id
}

\begin{abstract}
This paper describes the forms of prehistoric burials in South Sulawesi. The results of this study indicate that there are different forms of burial has been known since the Neolithic period to ethnography period. The burial forms are direct burial without the use of container, direct burial or indirect burial by using containers. The containers are to be used such as a rock (stone coffin, gravel pit, stone carving), wood (erong, duni, allung, passilliran), ceramics (balubu, bowl, jar), or simply wrapped with a cloth or mat. Grave orientation is generally east-west or toward the sacred mountain, in accordance with their beliefs. The burial of corpses is accompanied by a burial tomb in various provisions, such as ceramics, objects of metal (gold, copper and bronze), beads and bracelets. The patterned pre-Islamic burial system is still life in certain communities, for example various forms tomb in Tana Toraja and even in the early Islamic period.
\end{abstract}

Keywords: : Erong, Toraja, Grave, Beliefs, Ancestral spirits.

How to cite: Duli, A \& Rosmawati. (2018). Late Prehistoric Burial System in South Sulawesi. ELS Journal on Interdisciplinary Studies in Humanities, 1 (2), 134-144.

\section{Introduction}

Yet many studies reveal about the burial systems in South Sulawesi region in prehistoric times. Some archaeological studies show that prior to the influence of Islamic and European cultures, there have been known pre-Islamic burial systems performed by ethnic groups in South Sulawesi. Even, the burial customs that still characterize preIslamic cultures and prehistoric cultures still exist in some of indigenous communities such as the Kajang customary community, Tolotang-Towani, and the burial of Toraja people.

This paper briefly describes the forms of burial in South Sulawesi, particularly preIslamic burial or the burial which is still done by people who are not affected by Islamic culture. Some pre-Islamic burial sites scattered throughout South Sulawesi, especially on megalithic sites and the burial sites still in progress in non-Islamic communities, were the object of this study. Records of data were obtained from the visits to various sites in the area of South Sulawesi.

\section{Late Prehistoric Burial System in Indonesia}

The values and ideas of death are reflected in the social behavior embodied in various technological systems. Basically, the technological system includes two aspects, namely the material culture that is closely related to the ceremony and the activity of corpse care. The technological system directly linked to the death ceremony is any

\footnotetext{
${ }^{1,2}$ Faculty of Cultural Sciences Hasanuddin University 
material embodiment associated with ceremonial objects (Koentjaraningrat, 1977). The ceremonial objects include musical instruments to accompany singing, drama, spellreading and dance that have mythological significance in ritual activity (Peursen, 1976). The most important part of the series of death rites is a burial.

The oldest evidence of burial activity has been recorded approximately 500,000 years ago, with the discovery of excavation data on Homo Neanderthal fossils in Europe (Koentjaraningrat, 1977). The data gives an overview of burial ways and the objects of his grave. In Indonesia, Lawa Cave site (Sampung) represents the oldest data about burial activity. The data is the discovery of a human skeleton that is buried in a folded position (flexed position), with the hands under the chin or closing the eyes which are the burial ways of the Mesolithic age (Heekeren, 1972).

Some of the researches that have been done on the grave sites in Indonesia, such as Gilimanuk site, Gunung Piring, Plawangan and Anyar have provided many illustrations about the ways of burial. The excavation of the Gilimanuk site illustrates the complex way of burial with four burial patterns. The first pattern, identified as the primary burial, which includes one or two corpses, has various features in the burial. The second pattern, called the secondary burial, has a variety of arrangements. This second pattern still follows the pattern of skeletal fractures. The third pattern is a mixed grave. It is a combination of the first and the second pattern with many variations. The fourth pattern is a burial that using a container jars. This latter pattern is rarely embedded in the Gilimanuk site, which mostly use the sarcophagus grave container, i.e for the first, second and third patterns (Soejono, 1977).

The results of excavations at the Gunung Piring site (South Lombok) that had been done in 1976, obtained the data that one of the cultural components contained on the site characterize the remains of prehistoric activities, particularly on the aspects of burial. The discovery of the skeleton in the excavation shows that the way of burial is the primary burial without a container with a supine position (Nitihaminoto, 1978). On the other hand, a research conducted on Terjan and Plawangan sites in 1977 and 1978 had provided an idea of the existence of the site and its aspects. Based on the discovery of the skeleton of the Terjan site, which is in the longitudinal position of the northwest-southeast, with its head situated in the northwest, it can be concluded that the site is a Megalithic site. Meanwhile, the results of excavation at Plawangan site provide an evidence that the presence of burial remains by primary and secondary burial. Primary burial is done by putting the corpses directly in the soil and in the jar, while the secondary burial by using the jars (Sukender \& Rokhus Due Awe, 1981). A research conducted on Anyar site, West Java in 1979, had proved that the Anyar site has two ways of burial, the primary burial in containers using a cap, with the position of the corpse in a position of folded (flexed position) (Sukender, 1982).

Ethnographic studies of burial systems in the tribes in Indonesia archipelago, suggests that there are many burial system that still implemented in traditional society. One of the examples is the funeral system that took place in the death ceremony of the Sumba community, as described by Soelarto (1980) which consists of three stages of implementation, namely pre-burial, during burial and post-burial. In the pre-burial phase, some of the activities that occur in this phase are bathing the body, immersing the body with coconut water or with coconut oil. The body is placed in a squat position, with both knee bones broken. Both arms are bent to support the cheek. On the certain parts of the body, such as knees, heels, abdomen, chest and arm are wrapped in fabric or sarong. 
Sarong wrap is usually intended for woman's body. On the head and forehead stripped with a headband, then the corpse decorated with some jewelry such as necklaces and beads. Next, they lay the corpse at home for a few days. As long as the corpse is laid out on the veranda of the house, there are several ceremonies such as cutting the sacrificial animals every day. At this stage, the corpse is still treated like a living man, with meals and drinks served at every meal (Duli \& Hasanuddin, 2003).

At the funeral stage, there are two forms of burial, namely primary and secondary burial. During the primary burial, it is considered that the spirit of the deceased remains in the vicinity of human habitation and obliged to be maintained (Koentjaraningrat, 1958). The implementation of this primary burial is intended to wait for the loss of other physical elements, except for the bones. This primary burial is performed within a short period of time (one to several weeks) or over a long period of time (one to ten years). Initially, the implementation of the primary burial is carried out by bringing the corpse to the cemetery located around the village. Then, it is followed by laying the corpse in the coffin with the burial ground. Once the corpse is in the chest, then the casing is tightly closed and placed in a special place for the primary burial. Upon the completion of the secondary funeral, the bones will be reclaimed, purified, served with sacrifices and animal sacrifices. Then, a series of ceremonies is finalized and ended with a secondary burial, which included the coffin into the grave. In the post-burial stage, it is performed a spirit-raising ceremony, performed after the secondary burial on the third day. The ritual of raising the spirit is the spirit rises to the original source. The implementation of this ceremony is conducted around the grave and accompanied by betel nut and animal sacrifices. The sacrificial animals that are presented such as a dog which means a symbol of salvation.

Technology systems that are closely related to the execution of death can be seen based on the patterns of corpse care. In general, the pattern of corpse care includes four main features: buried, left to rot, burned and preserved. While the coronary care has three main objectives: putting the corpse in the place desired by society, helping the souls move into the spirit realm smoothly and recovering the living social relationships with the dead who are disturbed at the death (Koentjaraningrat, 1958). In the dimensions of corpse care, it is usually buried with or without the use of a grave container, such as a jar or a grave. Further, Koentjaraningrat (1958) states that:

"....... ceremonial tools that are very common everywhere are statues that have a function as symbols of the god or spirit of the ancestors who became the goal in the ceremony. Likewise, a mask is an important ceremonial tool of the religion of various tribes in the world. The mask symbolizes the gods and ancestors and it is used in the religious ceremonies in the form of dance or a game of the art of a sacred drama".

In this context, magical and masked ceremonies represent the ancestors of the ceremony to direct what he has to liberate people from the crisis (Kirby, 1983).

It is believed that the execution of death is a part of the system of ideas in the minds of the people who inhabit in Indonesia archipelago. The diversity of cultures in Indonesia also illustrates the diversity of social behavior as reflected in the existence of material cultures that survive the ritual's practice of death. In ethnographic studies in Indonesia, there is a uniformity of the idea that death is simply the process of displacement from one stage of life to another's level of life and is still widely accepted in the native cultures in Indonesia. This is in line with the understanding of the soul (in the world) and the spirit (in 
later life), which is still understood and practiced by the people of Batak Toba, Nias, Mentawai, Java, Toraja, Dayak Ngaju, Dayak Malok, Yamdena, Buru, people in Irian (Dyson \& Asharini, 1981; Kana, 1983; King, 1985; Koentjaraningrat, 1977; Nooy-Palm, 1979).

The human idea of soul and spirit is motivated by the psychological perception of the close relationship between man in the world and the ancestral spirits of the relationship with supreme power or dominant power that is usually only known through myth. This phenomenon has been formulated by Nooy-Palm (1979), regarding Toraja Sa'adan society:

“.... The gods are powerful and important but they are far off. Closer by and more familiar are the souls of the (more recently) dead, the ancestors of the West (to matua) and of the East (deata), and the spirits associated with specific location".

The relationship between human beings in the world and ancestral spirits in the realm of the spirit, takes place in the interests of the man. The relationship for various cultures in Indonesia archipelago was created in the form of dishes and prayers (Nooy-Palm, 1979; Kana, 1983; King, 1985; Koentjaraningrat, 1977). At the various native cultures in Indonesia archipelago, it still believes the spirit rest, both in the location and in the community. In general, the location of the spirit rest is considered to be on the mountain. Indigenous-oriented people assume that the spirit rest is at the tops of the mountain (Dyson \& Asharini, 1981; Nooy-Palm, 1979). In addition, there is also an opinion that the spirit world is located on the ground or the sea. To get there, the spirit needs to go through a long, vertical lane (Koentjaraningrat, 1977). For ocean-oriented societies usually indicate an island as the last resting place for spirits (Kana, 1983). For this society, the boat is considered as a vehicle of the spirit that will send it to the ancestors of nature (Kana, 1983). However, there is also land-oriented societies assuming that boat is a vehicle to the spirit world. It is related to the myth that their ancestors used to come by boat, such as the Toraja Enrekang ethnic myth (Duli, 2013; 2014; 2015).

For a society that implements two stages of death ritual, in the phase between the first and second stage rituals, it is believed that the spirit of the dead still lives around the community. In addition, they also believe that this time the spirit is bad or evil. This also happens to the spirits who can not get to the spirit world because they die unjustly (Dyson \& Asharini, 1981; Ellen, 1978; Kana, 1983; King, 1985; Koentjaraningrat, 1977; NooyPalm, 1979). Therefore, the rituals and treatments that will connect the journey of the spirit to the immortal world are absolutely necessary. The activities of the caretaker corpse in line with the notion of the process of transitioning the stage of life to the dead, can be categorized into three stages. The first step is to release individuals from their old society, the second stage is to prepare individuals to a new position, and the third stage is to release individuals to a new position or status (Koentjaraningrat, 1958).

The first stage of activities is embodied in the activities and ceremony of corpse care which explains the difference of the status among the deceased individuals with their old community. In various prehistoric death practices in Bali, corpses are left to rot in or around the residence, on stage, in death homes, or placed on the surface of the soil in the forest (Soejono, 1977).

This is similar to the habits of some communities in the Irian regions (Koentjaraningrat \& Harsja, 1963). In addition, there are also customs to bury the corpses 
as Dayak Ngaju people do in Borneo (Dyson \& Asharini, 1981) and some communities in Irian (Koentjaraningrat \& Harsja, 1963). Meanwhile, for others community, they burn the corpses and preservation (Koentjaraningrat \& Harsja, 1963). Essentially, this treatment is temporary in order to obtain the bones of the dead. In Tana Toraja such habits are also performed, especially for the people who come from the noble class (Duli \& Hasanuddin, 2003; Sandarupa, 2010).

In the second stage, the various activities are done to prepare individuals who move to the spirit world. At this stage, the dead receive food supplies (Dyson \& Asharini, 1981), as well as a drink commonly known as "travel oil" (Kana, 1983). At this stage, the principle is that the body is well prepared and decorated to be accepted by the ancestors on a boat that will take him to the unseen world (Kana, 1983). Then in the third stage, the ceremony is held to release the spirit to the last resting place in the ancestral realm. At this stage, the remains of a corpse or bone are sometimes just skulls, kept in their family's house or stored in a cave (Soejono, 1977) or burned (Dyson \& Asharini, 1981). The treatment of death that burns the corpses is mostly done in Kalimantan as well as in Irian, with various titles, such as ijambe (Dayak Ma'anyan) and tiwah (Dayak Ngaju).

In the execution of deaths, social aspect and relatives are difficult to separate from the ritual and religious aspects. In many respects, the review is different, often overlapping. As an implication of the idea concerning the nature of the spirit and the human obligation to facilitate the travel of its dead community members to the realm of the spirit, there is a habit of incorporating various things as the provisions for the dead soul of the individual. Generally, things attached to mortuary is a daily necessity that belongs to the deceased's personal property (Kana, 1983; Koentjaraningrat \& Harsja, 1963). In the meantime, they are also accompanying it with animals, such as buffalo (Nooy-Palm, 1979) or humans. The latter form develops the custom mengayau, which, in the opinion of Dyson \& Asharini (1981) states that:

".... It is actually associated with the implementation of rituals of death on the Dayak people, such as the Tiwah ceremony. To run the ceremony, the human head is required, so they seek their victims to the other group. This indigenous custom is a part of their belief systems that relate to their views of the hereafter, namely that the deceased person needs to be accompanied along the way to the world of spirits".

The same way done by Toraja people in the past (Kruyt, 1923-24; Nooy-Palm, 1980; Buijs, 2009). Furthermore, for the welfare of the spirit and preserving the bond with the living, some people laid down the food on the grave (Kana, 1983).

\section{The Burial Forms at the Age of Protohistory in South Sulawesi}

The Portuguese writer, Tome Pires, who visited Indonesia in 1512, mentioned that in South Sulawesi there are about 50 kingdoms whose people still worship idols. One proof that some kingdoms in Sulawesi at that time did not have Hindu influence but still possessed strong customs and beliefs of their ancestors by means of their own burials was Bugis-Makassar society. The practice of burial in Bugis-Makassar society at that time was still following the pre-historic tradition, that the corpse was buried in the east-west direction and on its grave included a number of burial supplies such as bowl, cepuk, jar, and even imported goods made in China, oysters, etc. Also, in this way of burial, it is a customary to give gold or silver mask or mask for the bodies of nobles or prominent people (Pelras, 1972). Macknight (1993) mentions that archaeological research and Portuguese 
news report that the Bugis Makassar people in pre-Islamic times practiced second burial (secondary), as the Toraja still practiced until the early 20th century by using caves as burial places.

The methods of burial on the people of South Sulawesi in the pre-Islamic period are generally based on prehistoric traditions, which are buried in the East-West direction with burial grounds such as bowls, cakes, locally-made jungle, and imported goods from China, Annam and others. Similarly, it is customary to give a mask of gold or a mask to the noble or prominent body (Tjandrasasmita, 1972).

The evidence of pre-Islamic burial in South Sulawesi shows that they buried the body by direct burial (primary burial) and indirect burial (secondary burial), some used containers and some did not use containers. The burials without containers are such by burying corpses into soil, rocks, caves, trees or into the water without containers (used), just wrapped in cloth or mat. The burials with containers are such burials using containers such as pottery (crock) and erong wood such as erong (Toraja), duni (Bugis), allung (Makassar, Mandar) (Duli, 1999; 2012; 2013; 2014; 2015). Pre-Islamic burial forms still continue even in the Islamic period in South Sulawesi, such as erong-shaped jirats, terraces of terraces, and tomb-shaped gravestones and tombstones (Rosmawati, 2008; 2011; 2013; 2017).

Figure 1. Pre-Islamic graves at Pambokboran and Mara'dia graves site (Majene)

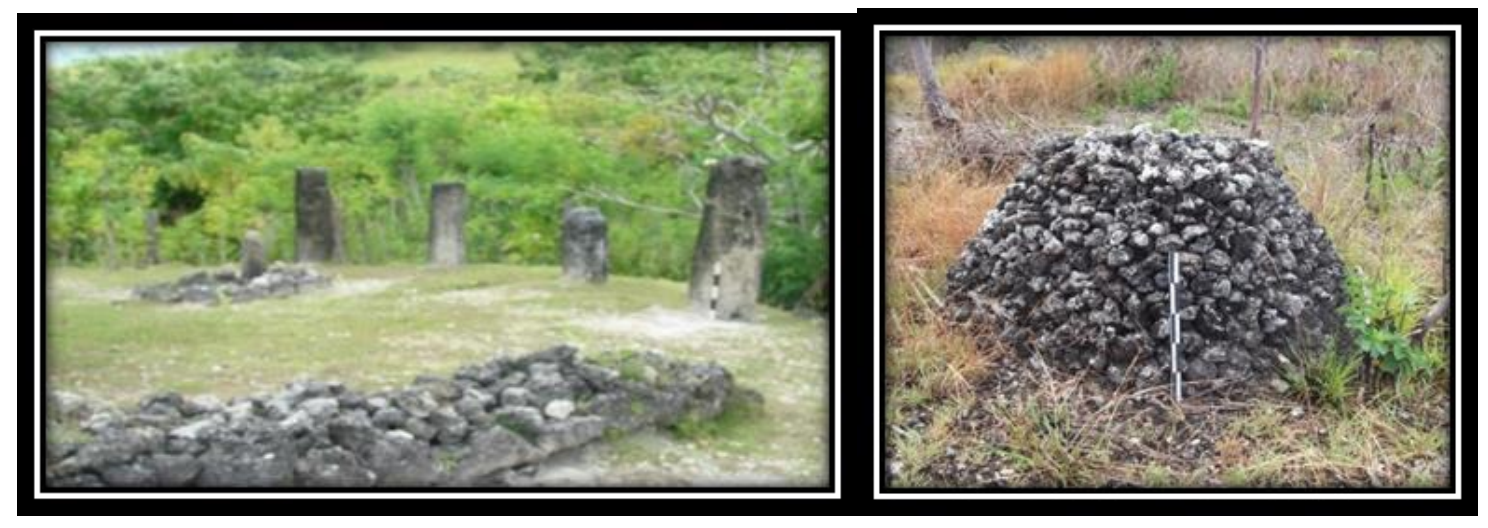

The burials without containers are generally either direct or first burial, whereas the burial with containers is generally as a second burial. The grave's orientation is generally north or east-west, in various forms, i.e grave into the ground above which there is an arrangement or pile of earth or rock resembling, mountains, square or terraces of terraces, such as those on the Pambokboran site (Majene), the pile stone (Toraja and Enrekang). There are also grave surfaces in the form of tie-shaped stone bracelets (circular, oval and square), such as those found in Tinco (Soppeng), Manipi (Sinjai) and Gattarang Keke (Bantaeng). The burials into carved stones are like stone crate on site Batu Pake 'Bojeng (Sinjai) and Liangpa' (Toraja). In addition, there are also burials using wooden crates, some of which are planted into the ground such as excavation at Tallo (Makassar) and Sigeri (Pangkep) sites, and some are placed in natural caves like those found on the TilleTille site and Pa'tumbukang (Selayar), Bira (Bulukumba), Enrekang, Mamasa, Toraja and Kalumpang (Duli, 2012). In the Bugis-Makassar society until the 17th century still recognize the habit of erecting stone menhir (ilamung mpatue) as a sign of covenant or sign of the grave, where under the stone menhir is sometimes found the ashes or bones of humans, especially for nobels people (Pelras, 2006). 
Figure 2. Temu bracelet which is estimated as a burial place on Onto site (Bantaeng) and jar as container of grave at Datu Mario site (Soppeng)
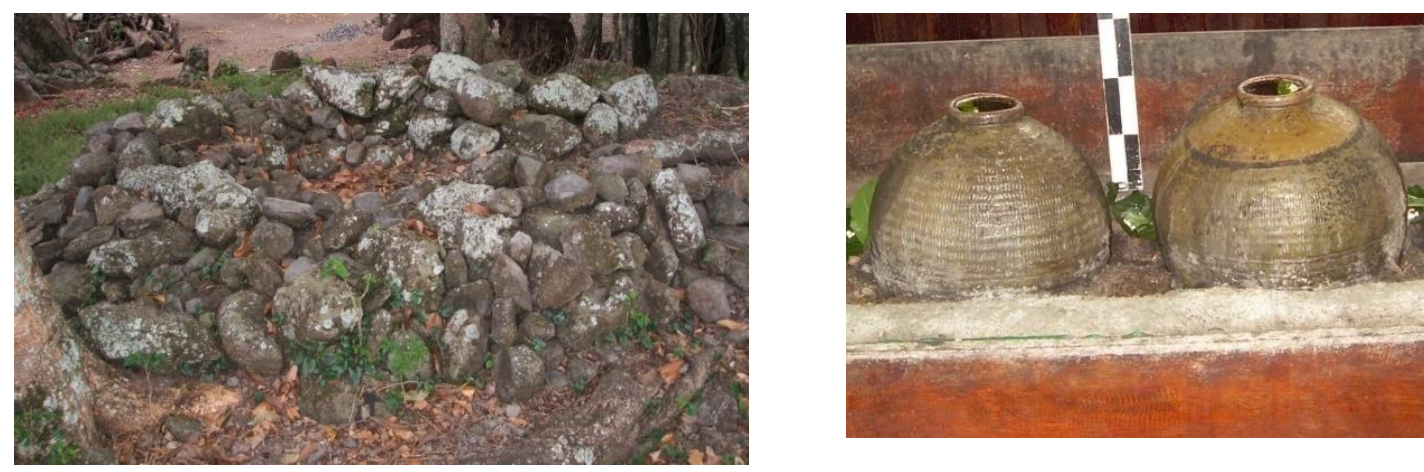

\section{The Burial Forms in Tana Toraja}

The shape and layout of the grave in a cemetery complex for the Toraja people in the past have been determined by their social stratification (tanak). At present, however, it is no longer valid and is determined by their respective economic capabilities. The forms of the tomb of the Toraja people can be described as follows:

1. Liang, the burial found in caves or niches either naturally or deliberately made as carved on stone walls. Liang consists of several forms, namely: (i) Liang alam, which form the burial by inserting corpses into the natural caves (lo'kok) as found in the foothills or rock mountains, then covered with small stone structures. The burial pores of Liang Alam do not use Erong eand for dead children before their teeth grow usually put into pottery. The form of burial is for the people who come from the kua-kua and tanak karurung. (ii) Liang Erong is burial by laying corpses in caves or niches using the Erong container. These are arranged in such a way that the social stratification marked by laying out, from high social stratification, is placed somewhere higher and vice versa. The social stratification can also be identified with the form Erong used. The grave with Erong, commonly called Liang Tokek (suspended), because the used Erong is laid or hung on the ceiling of the cave or the niche wall. (iii) Liangpa ', the grave that is carved into the surface of the stone wall which is in the form of a large cavity of various sizes according to the will and capabilities of each family. The door parts are made smaller with sizes of about $1 \mathrm{~m} \times 1 \mathrm{~m}$ and covered with wood. The corpse was wrapped in fabric and did not use Erong yet, but usually used a modern coffin that was shaped or rounded. Previously, Liangpa's burial form was only reserved for nobles but in recent anyone could be buried using the grave form depending on their economic ability. The forms of graves called Liang are usually together in a burial site which is a burial of a particular family or community. Thus, the layout, shape and shape of the burial ground in a burial complex may reflect social stratification such as the layout of a village when they are still alive in the world. 
Figure 3. Tomb of Erong and Passilliran in Tana Toraja
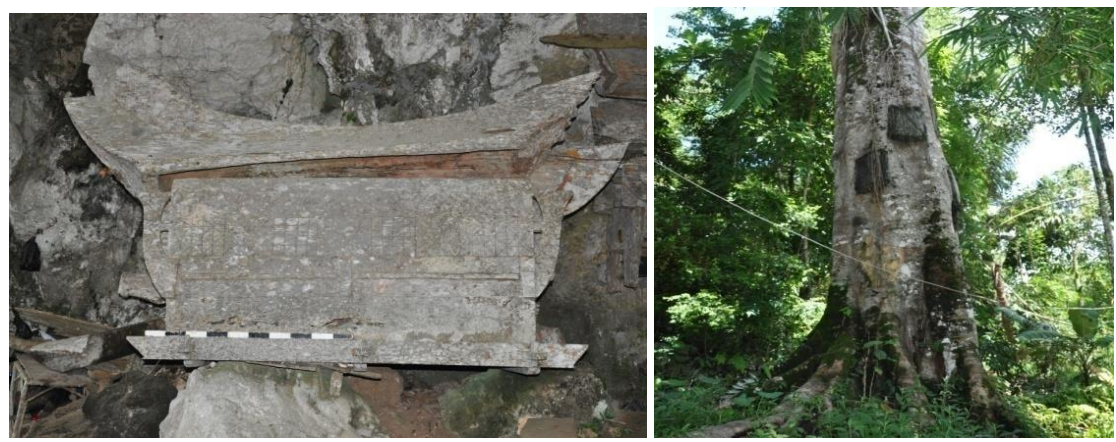

2. Tangdan, which is a custom-shaped burial house (Tongkonan) is usually placed on a hilltop or purposely elevated place, in Mamasa called Batutu. Materials from Tangdan buildings are all made of wood such as custom house building in general. The bodies contained in Erong or just wrapped in fabric, are placed in a room consisting only of one room with a sealed wall. In the past, the shape of the grave was only reserved for nobles, and now has grown in a form called Patane and can be used by anyone depending on their economic ability. The forms of burial Tangdan or Batutu can be seen on the Paladan site (Saluputti) and in the Mamasa area.

3. Patane is the development of the Tangdan that is a house-shaped grave. The difference is: (i) the material used to make Patane is from wood and cement; (ii) The Tangdan is usually placed on the top of the hill whereas Patane is placed anywhere in accordance with the wishes of the family or the wishes of the deceased; (iii) It serves as a place of funeral, whereas Patane serves only as a protective device (a kind of pyramid built on all the pores that are carved into rocks or in the ground); (iv) Tangdan is only for nobles whereas Patane can be used by anyone who is economically capable; (v) in terms of the development of time Tangdan develops and now is not used anymore in Tana Toraja society except in Mamasa. Tangdan and Patane are usually used in areas where there are less rocks, hills and mountains of rock, but modern Patane is nowhere in the Tana Toraja area.

4. Passilliran pia is a burial on a tree especially for children who died before growing teeth. The wooden tree used is from kayusipate, tarrak and kau-kau type, the corpse is placed in the crevices of the root or on the stem of the hole then the corpse is inserted into it and covered with fibers. Formerly, the form of the tomb is only intended for people who come from tanak kua-kua. In the past, people buried in stone or cave slits, then covered with stone blocks without using Erong or placed in the crevices of the root of a tree, particularly the corpse derived from tanak kua-kua or tanakung, the name of disillik or Passilliran's grave. However, in the present development, Passilliran is only known as the baby's grave on a wooden tree.

5. Lamunan is a burial by inserting the body into the ground. In the past, the form of Lamunan's grave was only intended for the baby who died in her mother's ruin or miscarriage, by inserting the corpse into the pottery and then being planted into the ground in the southwest of the house. In the past, there were also dead bodies buried in the ground, either using wooden crates or without boxes in other areas of Toraja ethnic areas, such as in Mamasa, Enrekang and Rongkong, especially in areas with no 
rocks. At present, many Toraja people are buried in such a way especially after the advent of Christian and Islamic influences.

\section{Conclusion}

The ways of burial in the people of South Sulawesi in pre-Islamic times are generally based on pre-historical tradition, which is buried East-West oriented or to the mountains with tombs such as bowls, cups, jars, and imported goods from China, Annam, objects of metal and others. The burial system can be burial directly (primary burial) and indirectly (secondary burial), some are using containers and some are not using the container. The burials without containers, .i.e by burying corpses into soil, rocks, caves, trees or into water without using a container, just wrapped in cloth or mat. The burials with containers, i.e burials using containers such as pottery (crock) and wooden prongs such as erong (Toraja), duni (Bugis), and allung (Makassar, Mandar).

The burials without containers are generally either direct or first burial, whereas burial with containers is generally as a second burial. The forms of the grave are the grave directly into the ground above which there is an arrangement or pile of earth or rock resembling a mountain shape, square or terraces, bracelets (circular, oval and square). There are also buried in stone carved, like stone crate, and Liangpa '(Toraja). Above the grave, there is a habit of erecting stone menhir (ilamung mpatue) as a sign of the grave, where under the menhir stone is sometimes found the existence of human remains or bones, especially for leading people.

There are also known as the type of burial that are plural like burial that uses Erong and Liang di Tana Toraja, earmarked for buried some frame of the corpse placed in caves, niches and cliffs of natural stone or special buildings. Erong containers made of uru, bitti and sandalwood. Before and after the corpse was buried, various rituals were performed, with the aim of the salvation of the ancestral spirits and the welfare of the people he left behind. When carrying out the ceremony of death, it is a momentum containing the social aspect, that is to strengthen the kinship between them, mutual cooperation and sharing.

\section{References}

Buijs, K. (2009). Kuasa Berkat Dari Belantara dan Langit, Struktur dan Transformasi Agama Orang Toraja di Mamasa Sulawesi Barat. Makassar: Ininnawa.

Duli, A. (1999). Berbentuk-Berbentuk Kubur Dalam Sistem Penguburan Orang Toraja, Suatu Studi Etnoarkeologi. Kongres dan Pertemuan Ilmiah Arkeologi VIII, in Yogyakarta, 15-18 Februari 1999.

(2012). Budaya Keranda Erong di Toraja, Enrekang dan Mamasa, Sulawesi Indonesia (Doctoral Dissertatio). Pusat Penyelidikan Arkeologi Global, Universiti Sains Malaysia-Penang, Malaysia. 2012.

(2013). The Mandu Coffin: A Boat Syimbol of Ancestral Spirits Among the Enrekang People of South Sulawesi. Journal RIMA (Review of Indonesian and Malaysian Affairs), Vol. 47(1), 2013. Canberra : Australian National University and University of New South Wales, Australian Defence Force Academy.

- (2014). Shape and Chronology of Wooden Coffins in Mamasa, West Sulawesi, Indonesia. Tawarikh, International Journal for Historical Studies, Vol. 5, April 2014. Bandung: ASPENSI. 
- (2015). Typology and Chronology of Erong Woodenn Coffins in Tana Toraja, South Celebes. Time and Mind, The Journal of Archaeology, Consciousnessand Culture, Vol. 8 (1), pp 3-10, Januari 2015. London: Routledge, Taylor and Francis Group.

Duli, A. \& Hasanuddin (ed). (2003). Toraja Dulu dan Kini. Makassar: Pustaka Refleksi.

Dyson, L. \& Asharini, M. (1980/1981). Tiwah Upacara Kematian pada Masyarakat Dayak Ngaju di Kalimantan Tengah. Jakarta: Proyek Media Kebudayaan Ditjen Kebudayaan Depdikbud.

Ellen, R. F. (1978). Nualu Settlement and Ecology, in VKI, 83. Gravenhage: The HagueMartinus Nijhoff.

Heekeren, H.R. van. (1972). The Stone Age of Indonesia. $2^{\text {nd }}$ ed. Gravenhage: The Hague- Martinus Nijhoff.

Kana, N. L. (1983). Dunia Orang Sewu. Jakarta: Sinar Harapan.

King, V. W. (1985). The Maloh of West Kalimantan. VKI, 108. Dordeesh-Cinnaminson: Foris Publications.

Kirby, E.T. (1983). Mask. in Grolier Academic Encyclopedia, 13. Grolier International, pp 196.

Koentjaraningrat. (1958). Ritus Peralihan di Indonesia. Jakarta: Balai Pustaka. (1977). Beberapa Pokok Antropologi Sosial. Jakarta: Dian Rakyat.

Koentjaraningrat \& Harsja W. B. (1963). (Ed). Penduduk Irian Barat. Djakarta: Penerbit Universitas.

Kruyt, A. C. (1923). De Toradja's van de Sa'dan, Massoeppoe en mamasa, in Bijdragen tot de Taal - Land-en Volkenkunde van Nederlandsch Indie. LXIII, pp 81-259. Amsterdam: 's Gravenhange.

Macknight. C.C. (1993). The Rise of Agriculture in South Sulawesi Befire 1600.

Nooy-Palm, H. (1979). The Sa'dan Toraja, A Study of Their Social Life and Religion. Vol.1: Organisation, Syimbols and Beliefs. KITLV, Verhandelingen, 87. The Hague: Nijhoff.

Nitihaminoto, G. et.al. (1978). Laporan Ekskavasi Gunung Piring (Lombok Selatan), in Berita Penelitian Arkeologi, No.17. Jakarta: Pusat Penelitian Arkeolgi Nasional.

Pelras, C. (1972). Sulawesi Selatan Sebelum Datangnya Islam Berdasarkan Kesaksian Bangsa Asiang, in Citra Masyarakat Indonesia, pp. 56-83.Jakarta: Sinar Harapan.

(2006). Manusia Bugis. Jakarta:Nalar.

Peursen, C. A. van. (1976). Strategi Kebudayaan (Terjemahan). Yogyakarta-Jakarta: Kansius-BPK Gunung Mulia.

Rosmawati. (2008). Pemaknaan Inskripsi Pada Makam kuno Katangka di Kabupaten Gowa (Master Thesis). Makassar: Unhas.

-(2011). Tipologi dan Perkembangan Bentuk Jirat dan Nisan Makam Kuno di Sulawesi Selatan. Jurnal Lensa Budaya, 6 (2). 
(2013). Tamadun awal Islam di Sulawesi Selatan, Indonesia: Dari Perspektif Arkeologi dan Sejarah (Doctoral Disertation). Pinang: PPAG USM-Malaysia.

- (2017). The manivestation of Malay and Local Cultural Acculturation at the Beginning of IsImamization at Luwu, Case Study at Lokko'e Tomb Complex, Palopo. Asian Journal of Social Sciences of Humanities. Vo. 6(2), May 2017.

Sandarupa, S. (2010). Rahasia Penguburan Bayi Toraja ke Dalam Pohon. Makassar: Fakultas Sastra, Universitas Hasanuddin.

Soejono, R.P. (1977). Sistem-Sistem Penguburan Pada Akhir Masa Prasejarah di Bali. Jakarta: Pusat Penelitian dan Pengembangan Arkeologi Nasional.

Soelarto, B. (1980). Pustaka Budaya Sumba, Jilid II. Jakarta: Proyek Pengembangan Media Kebudayaan Ditjen Kebudayaan Depdikbud.

Sukender, H. (1982). "Laporan Penelitian Kepurbakalaan di Sulawesi Tengah". Dalam Berita Penelitian Arkeologi,No. 25. Jakarta: Puslit - Arkenas.

Sukender, H. \& Rokus, D. A. (1981). Laporan Penelitian Terian dan Pelawangan, Jawa Tengah. BPA, No. 27.

Tjandrasasmita, U. (1972). Les Fouilles et L'Historie A Celebes Sud, in Archipel 3. Paris. 